\title{
Isolation and Preliminary Taxonomic Studies of Thermus Strains Isolated from Yellowstone National Park, USA
}

\author{
By MICHAEL J. MUNSTER, ANN P. MUNSTER, \\ JOHN R. WOODROW AND RICHARD J. SHARP* \\ Microbial Technology Laboratory, PHLS Centre for Applied Microbiology \& Research, \\ Porton Down, Nr Salisbury, Wiltshire SP4 OJG, UK
}

(Received 18 November 1985)

\begin{abstract}
Forty-eight strains of Thermus isolated from hot springs in Yellowstone National Park, Wyoming, USA, and eight reference strains were subjected to a numerical taxonomic analysis using Gower's coefficient $\left(S_{G}\right)$ with single and average linkage clustering. Two major groups were distinguished, which could be differentiated by colony morphology, ability to reduce nitrate and proteolytic activity. Cluster 1 contained Thermus aquaticus YT-1, the type strain of the species, and cluster 2 contained authentic strains of ' $T$. flavus' and ' $T$. thermophilus'. T. ruber was recovered as a single member cluster. The mol \% G $+\mathrm{C}$ of DNA from representative strains from each cluster was 64.4 to 66.8 for cluster $1,62.2$ to $67 \cdot 1$ for cluster 2 and 62.5 for T. ruber.
\end{abstract}

\section{INTRODUCTION}

Thermus aquaticus was first isolated from hot springs in Yellowstone National Park, Wyoming, USA, by Brock \& Freeze (1969). Strain YT-1, which became the designated type strain, was described as an aerobic, yellow pigmented, Gram-negative, heterotrophic bacterium with an optimum growth temperature of about $70^{\circ} \mathrm{C}$, and a pH optimum of 7.0 to 8.0 . Since this first description, Thermus strains have been recovered from thermal regions in Japan (Oshima \& Imahori, 1974), the USSR (Loginova \& Egorova, 1975), Iceland (Pask-Hughes \& Williams, 1977) and New Zealand (Cowan et al., 1984). Other sources of strains include streams receiving thermal effluent (Ramaley \& Hixson, 1970) and hot water systems (Brock \& Boylen, 1973; PaskHughes \& Williams, 1975).

This paper describes the isolation of 48 strains of Thermus from thermal areas in Yellowstone National Park, and a numerical analysis of these strains and of recognised reference strains including $T$. aquaticus YT-1, ' $T$. thermophilus', ' $T$. flavus' and $T$. ruber.

\section{METHODS}

Strains, sampling and media. Sixty-five hot springs and effluent channels were examined in four major thermal areas [Mud Volcano, Potts Basin, the Lower Geyser Basin (White Creek area) and Norris Geyser Basin] of Yellowstone National Park, Wyoming, USA. The temperature and $\mathrm{pH}$ of the pools or effluent channels were recorded at the time of sampling (Table I). Liquid samples were taken using sterile $10 \mathrm{ml}$ pipettes and transported in $5 \mathrm{ml}$ cryotubes (Sterilin). The samples were in transit for approximately 7 to $10 \mathrm{~d}$ before examination in the laboratory. The biomass was resuspended in the sample tubes and $0.5 \mathrm{ml}$ transferred to $10 \mathrm{ml}$ of Thermus medium (Brock, 1978). The samples were incubated for $24-48 \mathrm{~h}$ at $70^{\circ} \mathrm{C}$ and tubes showing evidence of growth were inoculated onto Thermus agar (Brock, 1978) and incubated for $24 \mathrm{~h}$ at $70^{\circ} \mathrm{C}$. Following three serial single colony transfers, a collection of 48 independent isolates was established (Table 1). Reference strains used were T. aquaticus strains YT-1 and Y-VII-51 B (Brock \& Freeze, 1969), Thermus sp. B (Williams, 1975), Thermus sp. X-1 (Ramaley \& Hixson, 1970), Thermus sp. T2 (ATTC 27737), 'T. flavus' (Saiki et al., 1972), 'T. thermophilus' (Oshima \& Imahori, 1974) and T. ruber (a gift from Dr R. A. D. Williams, London Hospital Medical School, London, UK). All strains were maintained as frozen suspensions in $10 \%(\mathrm{v} / \mathrm{v})$ glycerol at $-80{ }^{\circ} \mathrm{C}$. For routine culturing, Thermus liquid medium and Thermus agar were used (Brock, 1978). 


\section{Table 1. Origin of Thermus strains isolated from thermal areas in Yellowstone National Park, USA}

\begin{tabular}{|c|c|c|c|}
\hline \multirow[b]{2}{*}{ Strain reference no. } & \multirow[b]{2}{*}{ Sample site } & \multicolumn{2}{|c|}{$\begin{array}{l}\text { Properties of } \\
\text { sample site }\end{array}$} \\
\hline & & Temp. $\left({ }^{\circ} \mathrm{C}\right)$ & $\mathrm{pH}$ \\
\hline \multicolumn{4}{|l|}{ Cluster la } \\
\hline YS 001 & Firecracker Spring* & 76.5 & 9 \\
\hline YS 005 & Firecracker Spring* & $80 \cdot 5$ & 9 \\
\hline YS 012, YS 013, YS 014 & Unnamed pool Jt & 76 & $8 \cdot 2$ \\
\hline YS 015, YS 016, YS 017, YS 018 & Unnamed pool $\mathrm{K} \dagger$ & 75 & 6.95 \\
\hline YS 020 & Unnamed pool L† & 72 & 5.9 \\
\hline YS 023, YS 024, YS 049, YS 052 & Area of YW $135_{\ddagger}^{+}$ & $73 \cdot 3$ & $8 \cdot 5$ \\
\hline YS 025, YS 026, YS027 & Area of YW $134_{\ddagger}^{+}$ & $70 \cdot 2$ & $8 \cdot 5$ \\
\hline YS 028, YS 029 & Area of Verdant Spring + & $62 \cdot 2$ & $9 \cdot 3$ \\
\hline YS 031, YS 032, YS 033 & Pine Spring/Five Sisters $2_{+}^{+}$ & $72 \cdot 4$ & $8 \cdot 8$ \\
\hline YS 034, YS 035 & Pine Spring/Five Sisters $3_{+}^{+}$ & 72 & $7 \cdot 8$ \\
\hline YS 039, YS 041 & Pine Spring/Five Sisters $4 \ddagger_{\ddagger}^{\ddagger}$ & 55 & $10 \cdot 5$ \\
\hline YS 048 & Unnamed pool E† & $42 \cdot 9$ & 6 \\
\hline \multicolumn{4}{|l|}{ Cluster Ib } \\
\hline YS 007, YS 008 & Unnamed pool G† & $67 \cdot 5$ & 9 \\
\hline YS 009, YS 010 & Unnamed pool $\mathrm{I}^{\dagger}$ & 66 & $9 \cdot 3$ \\
\hline \multicolumn{4}{|l|}{ Cluster 2} \\
\hline YS 002 & Pine Spring/Five Sisters $4 \ddagger$ & 55 & $10 \cdot 5$ \\
\hline YS 011 & Unnamed pool $\mathrm{J} \dagger$ & 76 & $8 \cdot 2$ \\
\hline YS 019 & Unnamed pool $\mathrm{L} \dagger$ & 72 & 5.9 \\
\hline YS 021 , YS 022 & Area of YW $137_{+}^{+}$ & $68 \cdot 7$ & $7 \cdot 4$ \\
\hline YS 030 & Pine Spring/Five Sisters $1_{+}^{+}$ & $54 \cdot 8$ & $8 \cdot 2$ \\
\hline YS 037, YS 038, YS 051 & Pine Spring/Five Sisters $3 \ddagger$ & 72 & $7 \cdot 8$ \\
\hline YS 040 & Pine Spring/Five Sisters $4 \ddagger$ & 55 & $10 \cdot 5$ \\
\hline YS 044, YS 045 & Mary's Bay, Lake Yellowstone & NT & NT \\
\hline YS 047 & Unnamed pool $\mathrm{J} \dagger$ & 76 & $8 \cdot 2$ \\
\hline \multicolumn{4}{|l|}{ Unassigned strains } \\
\hline YS 003 , YS 004 & Firecracker Spring* & $76 \cdot 5$ & 9 \\
\hline YS 036 & Pine Spring/Five Sisters $3 \ddagger$ & 72 & $7 \cdot 8$ \\
\hline YS 050 & Unnamed pool I† & 66 & $9 \cdot 3$ \\
\hline
\end{tabular}

NT, Not tested.

* Lower Back Basin in Norris Geyser Basin.

+ Potts Hot Spring Basin, West Thumb area.

$\ddagger$ White Creek, Lower Geyser Basin. Spring nomenclature according to Brock (1978).

Numerical phenetic survel. Growth on single substrates was examined using basal Thermus medium modified by replacing tryptone and yeast extract with $2 \mathrm{~mm}-\left(\mathrm{NH}_{4}\right)_{2} \mathrm{SO}_{4}$ and by the addition of the selected carbon source at a concentration of $0 \cdot 2 \%(\mathrm{w} / \mathrm{v})$. Carbon sources used were erythritol, adonitol, arabinose, xylose, rhamnose, aesculin, dulcitol, galactose, glucose, inositol, fructose, mannitol, mannose, salicin, sorbitol, lactose, maltose, raffinose, sucrose, trehalose, dextrin, glycogen, inulin, starch, glycerol and the sodium salts of glutamate, acetate, citrate, formate, malate, propionate, pyruvate and succinate. Growth was examined by streaking a single colony onto a supplemented Thermus agar plate and incubating at $70^{\circ} \mathrm{C}$ overnight.

Antibiotic sensitivity was examined using cells from an overnight plate culture suspended in 2 ml Thermus medium. The $\mathrm{OD}_{5+0}$ was adjusted to 1.0 with medium to standardize cell density and $0 \cdot 1 \mathrm{ml}$ of the suspension was then spread over the surface of an agar plate and allowed to dry. Oxoid antibiotic sensitivity discs were applied to the agar and plates incubated at $70^{\circ} \mathrm{C}$ for $16-20 \mathrm{~h}$ before measuring the zones of inhibition.

Resistance to heavy metals was determined using $6 \mathrm{~mm}$ discs cut from a Whatman no. 1 filter paper, each disc impregnated with $20 \mu \mathrm{l}$ of heavy metal salts solution. The metals and concentrations used were sodium arsenate $(2 \mathrm{M})$, antimony potassium tartrate $(0.05 \mathrm{M})$, bismuth trichloride $(0.01 \mathrm{M})$ and sodium arsenite $(1 \mathrm{M})$. The discs were applied to seeded agar plates which were incubated for $16-20 \mathrm{~h}$ before zones of inhibition were measured.

Colony morphology was examined on Thermus agar plates; the degree of motility was dependent upon the time and temperature of incubation. The degree of 'spreading' of colonies was recorded after $2 \mathrm{~d}$ incubation at $70^{\circ} \mathrm{C}$.

Reduction of nitrate and nitrite was examined using the method of Cowan (1974) but using supplemented 
Thermus medium. Duplicate bottles of nitrate and nitrite broth were inoculated with single colonies, one bottle from each pair being examined after $\mathrm{I}$ and $3 \mathrm{~d}$ incubation at $70 \mathrm{C}$.

Oxidase (cytochrome $c$ oxidase) and catalase activity were examined using overnight cultures grown on Thermus medium and examined using the methods of Skerman (1967) and Kovacs (1956).

Sensitivity to $\mathrm{NaCl}$ was examined using Thermus medium supplemented with $3^{\circ}{ }_{0}(\mathrm{w}, \mathrm{v}) \mathrm{NaCl}$ : $\mathrm{pH}$ studies were done using the same medium adjusted to $\mathrm{pH} 5 \cdot 1$ and $6 \cdot 1$. Growth was examined following 1 and $3 \mathrm{~d}$ incubation at $70^{\circ} \mathrm{C}$.

Anaerobic growth of broth cultures $(10 \mathrm{ml})$ was examined following 1 and $3 \mathrm{~d}$ incubation at $70 \mathrm{C}$ in a $\mathrm{BBL}-\mathrm{Gas}$ Pak anaerobic jar with a $\mathrm{CO}_{2} / \mathrm{H}$ atmosphere.

Gelatin hydrolysis was studied using gelatin discs (Oxoid) added to $15 \mathrm{ml}$ Thermus medium and inoculated with a single colony from an overnight plate culture. Cultures were examined after 1 and $3 \mathrm{~d}$ incubation at $70^{\circ} \mathrm{C}$.

Casein hydrolysis was examined using a modification of the method of Gordon et al. (1973). Casein agar $(5 \mathrm{ml})$ was overlayered onto Thermus agar. After inoculation, plates were incubated for $24 \mathrm{~h}$ at $70 \mathrm{C}$ and examined for evidence of hydrolysis.

Starch hydrolysis was examined on starch agar plates (Cowan, 1974) prepared using Thermus medium as a base. Plates were examined for hydrolysis after 1 and $3 \mathrm{~d}$ incubation at $70^{\circ} \mathrm{C}$. Hydrolysis was determined using iodine and recorded as either restricted (hydrolysis in the immediate vicinity of the colony) or diffuse (hydrolysis of starch in the area surrounding the colony).

The phenetic data, comprising 71 characters for 48 fresh isolates and eight reference strains, were coded using multistate numerical coding and similarity coefficients were calculated using the coefficient of Gower (1971). The similarity coefficients were sorted using single linkage analysis and unweighted average linkage analysis (UPGMA) (Sneath \& Sokal, 1973).

Computations were done using an Acorn system 4 microcomputer with a $48 \mathrm{~K}$ memory interface with a RICOH PP1600 printer and Watanabe MIPLOT XI plotter. All programs were written in BASIC by J. R. Woodrow.

DNA analysis. A $200 \mathrm{ml}$ overnight culture of Thermus was harvested by centrifugation ( $3700 \mathrm{~g}$ for $10 \mathrm{~min}$ ) and washed twice in $10 \mathrm{mM}-\mathrm{CaCl}_{2}$. The bacterial pellet was resuspended in $10 \mathrm{ml}$ standard saline citrate (SSC) (Marmur \& Doty, 1962). Lysozyme was added to a final concentration of $0.2 \mathrm{mg} \mathrm{ml}^{-1}$, and the mixture incubated for $5 \mathrm{~min}$ at $37 \mathrm{C}: 2 \mathrm{ml} 10 \% \mathrm{SDS}$ were then added and mixed in quickly and gently. An equal volume of buffered (SSC) phenol was added and mixed with the lysate to form an emulsion. The mixture was centrifuged at $3000 \mathrm{~g}$ for $5 \mathrm{~min}$ and the upper aqueous layer collected in a separating funnel. Traces of phenol were removed by washing the aqueous layer twice with ether. The lower layer from the funnel was centrifuged for $20 \mathrm{~min}$ at $12000 \mathrm{~g}$ to remove any residual protein. The supernatant was collected and heated to $60^{\circ} \mathrm{C}$ for $10 \mathrm{~min}$ to remove any traces of ether. DNA was precipitated by the addition of 2 vols ice-cold ethanol and spooled onto glass rods. The DNA was washed three times in ice-cold ethanol and dried in a stream of nitrogen. The DNA was further purified by isopycnic centrifugation in caesium chloride (Munster, 1984). The DNA was finally resuspended in a small volume of sterile SSC to give a final DNA concentration of approximately $0.1 \mathrm{mg} \mathrm{m} \mathrm{m}^{-1}$.

The $\mathrm{mol} \% \mathrm{G}+\mathrm{C}$ was determined using the method of Marmur \& Doty (1962). The DNA melting temperature was measured using a Pye Unicam SP8 100 spectrophotometer fitted with an electrically heated cell holder and an SPX 876 series 2 temperature programme controller.

\section{RESULTS AND DISCUSSION}

The majority of the Thermus strains were isolated from the alkaline environments Potts Hot Spring Basin and White Creek (Table 1). The $\mathrm{pH}$ and temperature ranges from which Thermus strains were isolated varied from $\mathrm{pH} 6.0$ to $\mathrm{pH} 10.5$ and from $55^{\circ} \mathrm{C}$ to $80.5^{\circ} \mathrm{C}$. A temperature gradient existed across the pools and samples taken from the centre, where the temperature varied from $85^{\circ} \mathrm{C}$ to $93^{\circ} \mathrm{C}$, did not yield any Thermus strains. The isolation of strains from springs with $\mathrm{pH}$ values as high as 10.5 was unexpected, since Brock (1978) has reported optimum growth of strains at $\mathrm{pH} 7 \cdot 5-7.8$ with no growth above $\mathrm{pH} 9 \cdot 5$. However, strains have also been isolated from hot springs in Iceland at pH 10.0 (Kristjansson \& Alfredsson, 1983). Seven isolates grew well in the laboratory at $\mathrm{pH} 5 \cdot 1$ although the $\mathrm{pH}$ range of their natural environment ranged from $7 \cdot 4$ to $10 \cdot 5$. Of the seven strains isolated from environments below $\mathrm{pH} 7 \cdot 0$, three did not grow at $\mathrm{pH} 5 \cdot 1$ in the laboratory and four grew only weakly. It appears that the $\mathrm{pH}$ of the natural environment does not necessarily condition the optimum $\mathrm{pH}$ for growth in laboratory media.

At $37^{\circ} \mathrm{C}$ growth was either absent or very weak, and at $55^{\circ} \mathrm{C}$ only nine strains grew strongly. The optimum growth temperature appeared to be in the region of $70^{\circ} \mathrm{C}$, except for $T$. ruber, which did not grow satisfactorily at $70^{\circ} \mathrm{C}$. T. ruber appears to have a growth temperature 


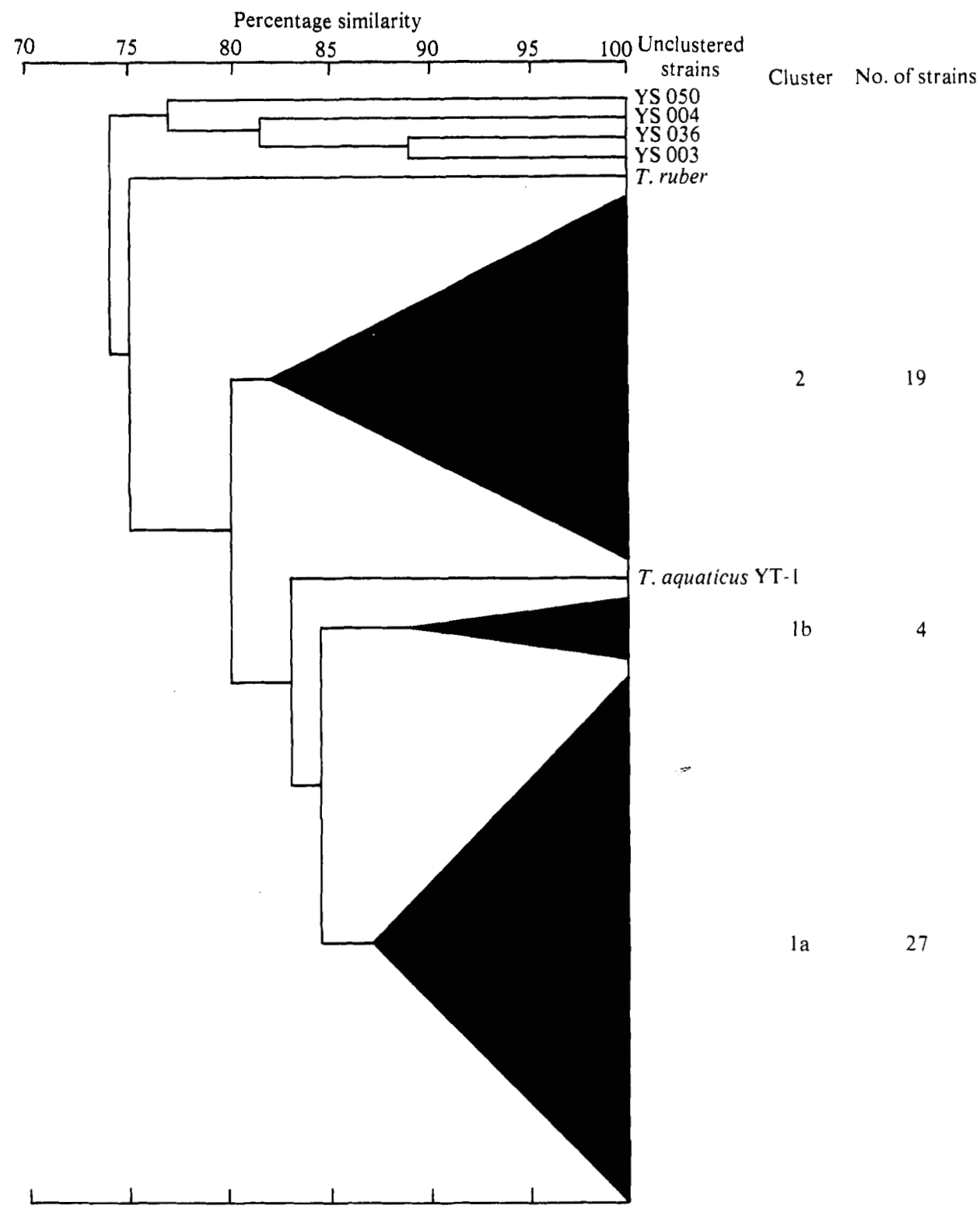

Fig. 1. Dendrogram depicting relationships between Thermus strains following analysis using the $S_{G}$ coefficient and UPGMA.

optimum considerably lower than that of the yellow and cream pigmented strains of Thermus and grew strongly at $45^{\circ} \mathrm{C}$. Similar studies on pink pigmented strains of $T$. ruber from Iceland (R. J. Sharp \& M. Parsons, unpublished observations) also indicate a temperature optimum in the region of $50-60{ }^{\circ} \mathrm{C}$.

T. aquaticus YT-1 was described as an aerobic organism (Brock \& Freeze, 1969); however, in this study 14 strains were found to grow as facultative anaerobes in the presence of nitrate. These strains were considered to produce nitrate reductase which enabled them to use nitrate as a terminal $\mathrm{H}^{+}$acceptor.

Studies of growth on single carbon sources showed that the majority of strains grew well on 
Table 2. Differential properties of the clusters

\begin{tabular}{|c|c|c|c|c|}
\hline \multirow[b]{3}{*}{ Character } & \multirow[b]{2}{*}{ Cluster ... } & \multicolumn{3}{|c|}{$\begin{array}{c}\text { Percentage of } \\
\text { positive reactions }\end{array}$} \\
\hline & & la & $1 \mathrm{~b}$ & 2 \\
\hline & No. of strains & 27 & 4 & 19 \\
\hline \multicolumn{2}{|c|}{ Spreading colonies } & 4 & 9 & 100 \\
\hline \multicolumn{2}{|c|}{ Starch hydrolysis } & 82 & 100 & 35 \\
\hline \multicolumn{2}{|c|}{ Casein hydrolysis } & 100 & 0 & 6 \\
\hline \multicolumn{2}{|c|}{ Gelatin hydrolysis } & 100 & 0 & 24 \\
\hline & 7 & 0 & 71 \\
\hline \multicolumn{2}{|c|}{$\begin{array}{l}\text { Reduction of } \mathrm{NO}_{3} \text { to } \mathrm{NO}_{2} \\
\text { Reduction of } \mathrm{NO}_{2} \text { to } \mathrm{NO}\end{array}$} & 4 & 0 & 71 \\
\hline \multicolumn{2}{|c|}{ Growth in anaerobic broth } & 25 & 100 & 82 \\
\hline
\end{tabular}

sodium pyruvate, sodium glutamate and sodium acetate, and that a few strains exhibited strong growth with lactose, galactose, maltose, sucrose, trehalose and sodium succinate. Growth on arabinose, mannitol and sodium citrate was either absent or only slight. Strain YS 036 was unique in exhibiting growth on all but three (erythritol, glycogen and starch) of the 33 carbon sources examined.

Analysis of the data by the $S_{\mathrm{G}}$ coefficient and UPGMA analysis indicated that the majority of strains (51) were allocated to two major clusters, defined at the $82 \%$ similarity level (Fig. 1). Confidence could be placed in the numerical classification since the average probability $(P)$ of an erroneous result was $2.56 \%$ when calculated on the basis of results for the 71 characters on 10 duplicate strains. This was well within the range of error generally considered acceptable (Sneath \& Johnson, 1972). Cluster 1 contained 32 strains, which were typified by extracellular amylase and protease production. The colonies were discrete, showing no evidence of cell motility. The cluster could be divided into subclusters $1 \mathrm{a}$ and $1 \mathrm{~b}$ at the $85 \%$ similarity level (Fig. 1). T. aquaticus YT- 1 clustered with the other strains in cluster 1 at the $83 \%$ similarity level. Cluster 2, defined at the $82 \%$ similarity level, contained 19 strains, all with spreading colony morphology indicating motility; $82 \%$ of the strains grew anaerobically in the presence of nitrate and $71 \%$ reduced nitrate to nitrite under aerobic conditions. The majority of the strains in cluster 2 grew at $\mathrm{pH} 5 \cdot 1$, and all seven strains which grew strongly at $\mathrm{pH} 5 \cdot 1$ were members of this cluster. $T$. aquaticus Y-VII-51B, Thermus spp. T2, X-1 and B, 'T. flavus', and ' $T$. thermophilus' were all members of cluster 2. Four isolates and T. ruber did not group in either cluster. However, three of these isolates, strains YS 036 and YS 003 , which clustered at the $89 \%$ similarity level, and YS 004 , which clustered with YS 036 and YS 003 at the $81.5 \%$ similarity level, formed a third distinct cluster. These three strains exhibited the widest range of carbon source utilization of all the isolates examined.

Analysis of the data by single linkage analysis again indicated that four strains in cluster 1 formed a subcluster ( $1 \mathrm{~b}$ ), clustering with the 27 strains of subcluster la at the $90 \%$ similarity level. These four strains differed from strains of subcluster la in being unable to hydrolyse gelatin and casein and in growing anaerobically in the presence of nitrate (Table 2).

The $\mathrm{mol} \% \mathrm{G}+\mathrm{C}$ of representative strains from the various clusters are presented in Table 3. These results do not suggest the existence of more than one distinct species, although the low $\mathrm{mol} \% \mathrm{G}+\mathrm{C}$ for $T$. ruber may be significant, and it would be relevant to examine other pink pigmented strains.

These data indicate the existence of two major taxa, which may be distinguished primarily on colony morphology and to a lesser degree on protease production, anaerobic growth, nitrate reduction and growth at $\mathrm{pH} 5 \cdot 1$. Three other minor groups were identified but their significance is not yet apparent. Cluster $1 \mathrm{~b}$, which was evident from both single linkage and UPGMA analysis, differed from cluster la in proteolytic activity and anaerobic respiration. In most other respects, it resembled cluster la and may be a subgroup of cluster 1. Strains YS 036, YS 003 and YS 004 may be the nucleus of a third taxonomic group. T. ruber showed little affinity to the other strains examined; it had a lower optimum growth temperature and its $\mathrm{mol} \% \mathrm{G}+\mathrm{C}$ differed markedly from that of the yellow, white and cream pigmented strains. 
Table 3. DNA base composition of selected strains of Thermus

Values of $T_{m}$ are means $\pm \mathrm{SD}$, and of mol $\% \mathrm{G}+\mathrm{C}$ are means, of three determinations.

\begin{tabular}{clcc} 
Cluster & \multicolumn{1}{c}{ Strain } & $T_{m}\left({ }^{\circ} \mathrm{C}\right)$ & $\mathrm{Mol} \% \mathrm{G}+\mathrm{C}$ \\
Ia & YS 013 & $95 \cdot 7 \pm 0 \cdot 24$ & $64 \cdot 4$ \\
la & YS 026 & $95 \cdot 7 \pm 0 \cdot 21$ & $64 \cdot 4$ \\
I & T. aquaticus YT-1 & $96 \cdot 7 \pm 0 \cdot 21$ & $66 \cdot 8$ \\
Ib & YS 007 & $96 \cdot 1 \pm 0 \cdot 14$ & $65 \cdot 4$ \\
Ib & YS 010 & $96 \cdot 1 \pm 0 \cdot 09$ & $65 \cdot 4$ \\
2 & YS 019 & $95 \cdot 9 \pm 0 \cdot 09$ & $64 \cdot 9$ \\
2 & YS 040 & $96 \cdot 3 \pm 0 \cdot 38$ & $65 \cdot 8$ \\
2 & B & $96 \cdot 8 \pm 0 \cdot 24$ & $67 \cdot 1$ \\
2 & T2 & $96 \cdot 7 \pm 0 \cdot 24$ & $66 \cdot 8$ \\
2 & X-1 & $96 \cdot 0 \pm 0 \cdot 01$ & $65 \cdot 1$ \\
2 & T. aquaticus Y-VII-51B & $94 \cdot 8 \pm 0 \cdot 24$ & $62 \cdot 2$ \\
2 & 'T. thermophilus' & $96 \cdot 2 \pm 0 \cdot 62$ & $65 \cdot 6$ \\
2 & 'T. flavus' & $96 \cdot 2 \pm 0 \cdot 24$ & $65 \cdot 6$ \\
- & YS 036 & $96 \cdot 1 \pm 0 \cdot 09$ & $65 \cdot 4$ \\
- & T. ruber & $94 \cdot 9 \pm 0 \cdot 09$ & $62 \cdot 5$
\end{tabular}

The designation of ' $T$. flavus' and ' $T$. thermophilus' as separate taxa may need to be reconsidered since both appeared in cluster 2 along with T. aquaticus Y-VII-51B and Thermus spp. B, T2 and X-1. T. aquaticus YT-1, which is designated as the type strain, did not cluster with the other $T$. aquaticus reference strain included in the study. Studies of a larger group of strains, including isolates from geographically separate environments, should clarify, if not answer, some of the questions raised in this study.

This work was supported by a Health and Safety Executive Grant. The authors would also like to take this opportunity to thank Fred Hirschman and Milanda Vachuda, for their help and extensive tour of the Norris Geyser Basin during our visit in August 1983; Caroline Bowditch, for technical assistance in isolating the strains; and Tony Atkinson and Tony Williams, for helpful discussions during the preparation of this manuscript.

\section{REFERENCES}

Brock, T. D. (1978). Thermophilic Microorganismis and Life at High Temperatures. New York: Springer Verlag.

Brock, T. D. \& Freeze, H. (1969). Thermus aquaticus gen. $\mathrm{n}$ and $\mathrm{sp}$. $\mathrm{n}$., a non-sporulating extreme thermophile. Journal of Bacteriology 98, 289297.

Brock, T. D. \& Boylen, L. K. (1973). Presence of thermophilic bacteria in laundry and domestic hot water heaters. Applied Microbiology 25, 72-76.

Cowan, S. T. (1974). Cowan and Steel's Manual for the Identification of Medical Bacteria, 2nd edn. Cambridge: Cambridge University Press.

Cowan, D. A., Daniel, R. M., Martin, A. M. \& MoRGAN, H. W. (1984). Some properties of a betagalactosidase from an extremely thermophilic bacterium. Biotechnology and Bioengineering 26, $1141-1145$.

Gordon, R. E., Haynes, W. C. \& Pang, C. H. (1973). The Genus Bacillus. Washington, DC: United States Department of Agriculture.

Gower, J. C. (1971). A general coefficient of similarity and some of its properties. Biometrics 27, 857874.

Kovacs, N. (1956). Identification of Pseudomonas pyocyanea by the oxidase reaction. Nature, London 178, $703-705$.
Kristjansson, J. K. \& Alfredsson, G. A. (1983). Distribution of Thermus spp. in Icelandic hot springs and a thermal gradient. Applied and Environmental Microbiology 45, 1785-1789.

Loginova, L. G. \& Egorova, L. A. (1975). An obligately thermophilic bacterium Thermus ruber from hot springs in Kamchatka. Microbiology 44, $661-665$.

MARMUR, J. \& Doty, P. (1962). Determination of the base composition of deoxyribonucleic acid from its thermal denaturation temperature. Journal of Molecular Biology 5, 109-118.

Munster, M. J. (1984). A study of the genetics of the extreme thermophilic bacilli. PhD thesis, CNAA.

OsHIMA, T. \& IMAHORI, K. (1974). Description of Thermus thermophilus (Yoshida \& Oshima) comb. nov., a non-sporulating thermophilic bacterium from a Japanese thermal spa. International Journal of Systematic Bacteriology 24, 102-112.

Pask-Hughes, R. A. \& Williams, R. A. D. (1975). Extremely thermophilic Gram-negative bacteria from hot tap water. Journal of General Microbiology 88, 321-328.

Pask-Hughes, R. A. \& Williams, R. A. D. (1977). Yellow-pigmented strains of Thermus spp. from Icelandic hot springs. Journal of General Microbiology 102, 375-383. 
RAMALEy, R. F. \& Hixson, J. (1970). Isolation of a nonpigmented, thermophilic bacterium similar to Thermus aquaticus. Journal of Bacteriology 103, 527-528.

SAIKI, T., KimURA, R. \& ARIMA, K. (1972). Isolation and characterisation of extremely thermophilic bacteria from hot springs. Agricultural and Biological Chemistry 36, 2357-2366.

SKerman, V. B. D. (1967). A Guide to the Identification of the Genera of Bacteria. Baltimore: Williams \& Wilkins.
SNeath, P. H. A. \& Johnson, R. (1972). The influence on numerical taxonomic similarities of errors in microbiological tests. Journal of General Microbiology 72, 377-392.

SNEATH, P. H. A. \& Sokal, R. R. (1973). Numerical Taxonomy. San Francisco: W. H. Freeman \& Co.

Williams, R. A. D. (1975). Caldoactive and thermophilic bacteria and their thermostable proteins. Science Progress 62, 373-393. 